\title{
KETAHANAN SOSIAL KOMUNITAS ADAT JALAWASTU TERHADAP PERUBAHAN SOSIAL DI DESA CISEUREUH KABUPATEN BREBES
}

\author{
Hendra Pramudya \\ Politeknik Kesejahteraan Sosial dan e-mail: pramudya18hp@gmail.com \\ Theresia Martina Marwanti \\ Politeknik Kesejahteraan Sosial Bandung, martina.wanti@gmail.com \\ Yana Sundayani \\ Politeknik Kesejahteraan Sosial Bandung, yana_sundayani@yahoo.com
}

\begin{abstract}
The Jalawastu Indigenous Community is a community group that still maintains traditional values and traditions, in carrying out daily activities. Social resilience refers to the social unity of individuals, organizations or communities that have aspects of coping capacities, adaptive capacities and transformative capacities with various environmental and social changes. This study aims to determine the resilience of the Jalawastu Indigenous community to social change in Ciseureuh Village, Keanggungan District, Brebes Regency. The method used in this study is a qualitative research method. This research provides a deeper understanding of the social resilience of the Jalawastu Indigenous Community in the face of social change. Data collection techniques used are in-depth interviews, observation, and documentation studies. The results of the study stated that the Jalawastu Indigenous Community still has a fairly good social resilience in responding to social changes. Aspects of coping abilities are marked by still holding high traditional values in deliberation and family solidarity. The aspect of adaptability in responding to social change is carried out while maintaining customary values and accepting social changes that are beneficial to the community. Regarding the aspect of transformational capacity, the Jalawastu Indigenous Community is still in the process of making changes for the better to maximize the available local potential. The Jalawastu Indigenous Community still has good social resilience in facing social changes in Ciseureuh Village, Keanggungan District, Brebes Regency.
\end{abstract}

Keywords:

Social Resilience; Social Change; Indigenous Communities

\begin{abstract}
Abstrak
Komunitas Adat Jalawastu merupakan kelompok masyarakat yang masih mempertahankan nilia-nilai dan tradisi adat, dalam melakukan aktifitas hari-hari. Ketahanan sosial merujuk pada kesatuan sosial individu, organisasi atau komunitas yang memiliki aspek dalam kemampuan memecahkan masalah, kemampuan adaptasi dan kemampuan bertransformasi dengan berbagai perubahan lingkungan dan sosial. Penelitian ini bertujuan untuk mengetahui ketahanan komunitas Adat Jalawastu terhadap perubahan sosial di Desa Ciseureuh Kecamatan Ketanggungan Kabupaten Brebes. Metode yang digunakan dalam penelitian ini adalah metode penelitian kualitatif. Penelitian ini memberikan pemahaman lebih mendalam mengenai ketahanan sosial Komunitas Adat Jalawastu dalam menghadapi perubahan sosial. Teknik pengumpulan data yang dilakukan adalah dengan wawancara mendalam, observasi, dan studi
\end{abstract}


dokumentasi. Hasil penelitian menyebutkan bahwa Komunitas Adat Jalawastu masih memiliki ketahanan sosial yang cukup baik dalam merespon perubahan sosial. Aspek kemampuan pemecahan masalah ditandai dengan masih menujung tinggi nilai adat dalam bermusyawarah dan solidaritas kekeluargaan. Aspek kemampuan adaptasi dalam mersepon perubahan sosial dilakukan dengan tetap menjaga nilai adat dan menerima perubahan sosial yang bermanfaat bagi masyarakat. Terkait dengan aspek kemampuan transformasi, Komunitas Adat Jalawastu masih dalam proses melakukan perubahan kearah yang lebih baik untuk memaksimalkan potensi lokal yang tersedia. Komunitas Adat Jalawastu masih memiliki ketahanan sosial yang cukup baik dalam menghadapi perubahan sosial di Desa Ciseureuh Kecamatan Ketanggungan Kabupaten Brebes.

\section{Kata Kunci:}

Ketahanan Sosial; Perubahan Sosial; Komunitas Adat

\section{PENDAHULUAN}

Indonesia negara multikulural yang memiliki keanekaragaman suku, budaya, bahasa dan kearifan lokal yang berwarna disetiap daerahnya. Beberapa didalamnya telah mengalami distorsi terkena dampak perubahan sosial dari kemajuan teknologi dan pengaruh globalisasi. Namun, beberapa yang lainnya masih menjaga dan melestarikan nilai adat, tradisi dan kearifan lokal dalam melakukan aktivitas sehari-hari. Salah satu yang masih mempertahankan keanekaragaman nilai adat dan tradisi adalah Komunitas Adat Terpencil (KAT). Berdasarkan data kementerian Sosial Republik Indonesia Tahun 2020 berjumlah 150.222 Kepala Keluarga komunitas adat. Berdasarkan data Aliansi Masyarakat Adat Nusantara (AMAN) Tahun 2020 terdapat 2.359 komunitas adat di seluruh Indonesia, dengan jumlah individu sekitar 17 juta orang.

Komunitas Adat Jalawastu merupakan komunitas adat yang terletak di Desa Cisereuh Kecamatan Ketanggungan Kabupaten Brebes Provinsi Jawa Tengah. Komunitas Adat Jalawastu berkomunikasi dalam kehidupan sehari-hari menggunakan bahasa sunda. Berdasarkan data Desa Cisereuh Tahun 2021, komunitas adat Jalawastu memiliki 160 Kepala
Keluarga dengan jumlah total masyarakatnya adalah 296 jiwa. Jumlah rumah yang ada di Komunitas adat Jalawastu hanya terdapat 111 Rumah. Di Desa Ciseureh terdapat tiga dusun, diantaranya, dusun Jalawastu, Garogol dan Salagading. Namun, dari ketiga dusun tersebut hanya dusun Jalawastu, yang hingga saat ini masih menjaga kearifan lokal dan budaya yang ada dari zaman leluhur yang diwarisi dari generasi ke generasi.

Komunitas Adat Jawalastu sampai saat ini masih mempertahakan kegiatan upacara adat dan tradisi seperti seperti, ngasa, babarit, tundan, sedekah bumi, tutulak, tong-tong breng, cako dan ngaguyang kuwu. Ada yang dilakukan rutin setiap tahun seperti tradisi ngasa, yang dilakukan pada mangsa ke sanga di hari selasa kliwon untuk memanjatkan doa agar terhindar dari mala petaka dan mendapatkan hasil panen yang melimpah. Beberapa tradisi yang lainya dilakukan tatkala ada kejadian tertentu seperti, tong-tong breng merupakan upacara adat yang dilakukan sebagai upaya untuk mencari orang yang hilang di sekitar wilayah Komunitas Adat Jalawastu.

Selain itu, Komunitas Adat Jalawastu juga memiliki larangan atau pantangan yang tidak boleh dilakukan (pamali) oleh masyarakat yang berada di wilayahnya, sebab 
apabila dilakukan akan mendatangkan bala atau malapetaka. Larangan tersebut diatantaranya yang mengatur tentang seni bangunan yang tidak diperbolehkan menggunakan bahan yang berasal dari semen, bata, genteng, dan juga keramik, di bidang pertanian tidak diperbolehkan untuk menanam bawang merah, kacang tanah, kacang hitam, dan juga kedelai, di bidang peternakan tidak diperbolehkan untuk memelihara kerbau, domba, ikan merah (ikan emas), dan angsa, dan di bidang kesenian tidak diperbolehkan untuk mengadakan kesenian wayang, nabuh/membunyikan gong. Sampai saat ini masyarakat Jalawastu masih mematuhi pantangan dan larangan tersebut, yang mana nilai-nilai budaya dan tradisi adat telah di tetapkan dalam Peraturan Desa Nomor 1 Tahun 2016 tentang Penetapan Desa Adat Jalawastu.

Komunitas Adat Jalawastu sampai saat ini masih mempertahankan adat dan tradisi yang diwarisi turun-temurun. Namun, saat ini tidak semua kegiatan selalu aktif yang diikuti oleh seluruh masyarakat. Sejauh ini hanya kegiatan tahunan saja seperti ngasa yang masih mengundang antusiasme yang tinggi dari masyarakat Jalawastu bahkan masyarakat luas. Beberapa yang sifatnya kegiatan rutin seperti babarit, upacara adat yang dilaksanakan pada hari Selasa Kliwon, yang bertujuan untuk menjaga kerukunan masyarakat mengalami jumlah penurunan partisipasi warga masyarakat Jalawastu dan Desa Ciseureuh. Selain itu, pengaruh globalisasi dari perkembangan teknologi informasi dan transportasi mempengaruhi nilai-nilai masyarakat dalam berperilaku dan bekerja untuk memenuhi kebutuhan sehari-hari sebagai bentuk adaptasi sosial yang dilakukan oleh Komunitas Adat Jalawastu.

Struktur sosial yang ada di masyarakat juga melemah, hal ini diakibatkan karena beberapa generasi yang mewarisi tradisi dan budaya masyarakat memilih untuk keluar dari
Komunitas Adat Jalawastu dan tinggal di Dusun Garogol dan Salagading, kedua dusun lainnya yang berada di Desa Cieseureuh dan beberapa memilih untuk merantau di Kota dengan alasan agar tidak terikat dengan peraturan adat dan lebih mudah untuk mendapatkan pekerjaan yang lebih. Hal ini mengakibatkan menurunnya jumlah generasi penerus yang tinggal menetap langsung ditempat komunitas adat, sehingga mengurangi partisipasi keikutsertaan masyarakat dalam mengelola kearifan Komunitas Adat Jalawastu.

Menurut Leitch dalam Agus Suwigyo dan Rhoma D.A.Y (2018:96) menjelaskan ketahanan sosial secara konseptual didefinisikan sebagai kemampuan individu dan kelompok untuk secara tepat waktu bertindak ketika keadaan stabil dan segera beradaptasi, mengatur diri dan tetap aktif terlibat dalam merespons kondisi yang tak menentu. Konsep tersebut mengandung tiga dimensi pokok, yaitu kemampuan atau kapasitas untuk mengidentifikasi dan mengelola persoalan (coping capacities), kemampuan untuk menyesuaikan diri pada kondisi tak menentu (adaptive capacities), dan kemampuan berubah menyesuaikan tuntutan kondisi yang juga berubah (transformative capacities).

Menurut Betke dalam Marwanti, dkk (2017:283) ketahanan sosial merupakan suatu proses dimana komunitas mampu mengelola dirinya untuk bertahan menghadapi kesulitan untuk menciptakan makna dalam mempertahankan kehidupan yang memberikan kontribusi kepada orang-orang di sekitar mereka. Dalam hal ini ketahanan yang dimaksudkan merupakan suatu bentuk kemampuan utuk mengatasi masalah, dan menyesuaikan diri dan memberikan partispasi masyarakat dalam menghadapi perubahan sosial dalam kehidupannya.

Menurut Daud Bahransyaf dan Ratih Probosiwi (2013:226) mengemukakan 
ketahanan sosial merupakan suatu konsep yang diperlukan oleh masyarakat untuk menjaga, melindungi dan mengembangkan perlindungan sosial, partisipasi masyarakat, pengendalian terhadap konflik dan kearifan lokal dalam mengelola sumber daya alam dan sosial. Masyarakat akan mengalami ketahanan sosial dengan terpenuhinya kebutuhan terhadap pelayanan sosial yang dinamis, sensitif dan komprehensif, terbentuknya sistem pengembangan sosial untuk masing-masing individu sehingga mereka mampu melakukan penyesuaian otomatis terhadap perubahan sosial yang terjadi, dengan meningkatkan kualitas hidup manusia sesuai dengan hak asasi universal (progressive).

Menurut Muhamad Fakhry (2016:234) Ketahanan sosial merupakan sebuah respons adaptif suatu masyarakat terhadap berbagai macam ancaman yang diaktualisasikan melalui beberapa proses, yaitu pertama melalui pemulihan, kemudian kontinuitas (keberlanjutan) yang ditandai dengan adanya pertumbuhan, kemampuan masyarakat untuk dapat mengatasi berbagai macam gangguan sehingga terbebas dari kesulitan yang dihadapi dan proses yang dapat membawa masyarakat kepada sebuah kondisi yang lebih baik dari sebelumnya.

Keck dan Sakdapolrak (2013:10) mendefinisikan ketahanan sosial yang terdiri dari tiga dimensi: Coping capacities, yaitu kemampuan aktor sosial untuk mengatasi dan menyelesaikan segala macam masalah; Adaptive capacities, yaitu kemampuan untuk belajar dari pengalaman masa lalu dan menyesuaikan diri dengan tantangan masa depan dalam kehidupan sehari-hari; Transformative capacities, yaitu kemampuan untuk merangkai lembaga yang mendorong kesejahteraan individu dan ketahanan masyarakat yang berkelanjutan terhadap krisis di masa depan.
Menurut Soekanto dan Sulistyowati (2013:22) masyarakat merupakan sekelompok manusia yang telah hidup bersama, yang telah membangun kesatuan sosial dan kerja sama serta memiliki kebiasaan-kebiasan dalam menjalani aktivitas kehidupan yang selalu bergerak atau berubah.

Menurut Keraf (2010:361) komunitas adat merupakan merupakan masyarakat yang hidup berdasarkan asal-usul dan garis keturunan di atas suatu wilayah adat yang memiliki kedaulatan atas tanah dan kekayaan alam, serta kehidupan sosial budaya yang diatur oleh lembaga adat yang mengelola keberlangsungan masyarakat. Di tengah perkembangan dari perubahan sosial yang signifikan di era saat ini, kominutas adat selalu menjaga dan melestarikan nilai-nilai kearifan lokal yang telah diwariskan secara teruntemurun dalam melaksanakan pemenuhan kebutuhan sehari-hari dan dalam menjalakan sistem sosial di dalamnnya.

Menurut Jacobus Ranjabar (2017:7) menyatakan bahwa perubahan sosial merupakan perubahan baik pada fungsi maupun pada struktur sosial yang didukung oleh nilai-nilai dan norma-norma kebudayaan yang terjadi sebagai akibat dari kegiatankegiatan baru. Perubahan sosial akan selalu begerak secara dinamis dan akan terus mengalami perkembangan disuatu masyarakat. Komunitas adat juga akan mengalami perubahan sosial seiring dengan berjalanya waktu mengingat terdapat juga penemuanpenemuan yang baru, perkembangan struktur sosial, munculnya suatu inovasi, perubahan lingkungan hidup dan perubahan ukuran/komposisi penduduk dalam memunuhi kebutuhan sehari-hari. Dimana hal tersebut turut serta mempengaruhi ketahanan sosial disuatu masyarakat.

Komunitas adat dapat memiliki ketahanan sosial yang baik apabila mampu dan 
memiliki kapasitas untuk memecahakan masalah sesuai tuntutan kebutuhan saat ini, memiliki kapasitas dalam beradaptasi, dan melakukan transformasi dalam mengikuti laju perkembangan perubahan sosial dengan tetap melestarikan nilai dan ada tradisi yang telah diwarisi secara turun-temurun dari hingga saat ini.

Menurut Adi Fahrudin (2012:59) pekerjaan sosial adalah pekerjaan yang berusaha untuk meningkatkan keberfungsian sosial individu atau kelompok dengan kegiatankegiatan yang dipusatkan pada hubunganhubungan sosial mereka yang merupakan interaksi orang dan lingkungannya. Dalam hal ini pekerja sosial memiliki peranan yang penting dalam upaya mengatasi permasalahan yang ada komunitas adat salah satunya pengaruh perubahan sosial yang berdampak pada ketahanan sosial masyarakat dalam mengatasi masalah kesejahteraan sosial.

Menurut Zastrow (2010:13) Pekerjaan Sosial adalah sebagai profesi terdepan dalam pemberian pelayanan sosial untuk membantu orang, baik secara individual, kelompok, keluarga, maupun masyarakat, dalam memecahkan rnasalah sosial yang dihadapinya. Tanggung jawab inilah yang menjadi misi utama Pekerja Sosial. Misi utama Pekerja Sosial bukan sekedar membantu pemecahan masalah, tetapi juga menciptakan kondisikondisi kemasyarakatan pokok yang menunjang pencapaian tujuan itu.

Menurut Enkeu Agiati, dkk. (2010:93) Pekerjaan Sosial merupakan profesi pertolongan yang berhubungan dengan pemberdayaan KAT dalam upaya meningkatkan dan mengembangkan potensi, kemampuannya serta sistem sumber yang dimilikinya. Peranan-peranan yang dapat dilakukan oleh profesi pekerjaan sosial dalam usaha untuk meningkatkan kesejahteraan sosial Komunitas Adat melalui pengembangan potensi dan kemampuannya sesuai dengan yang terdapat di daerahnya, antara lain advocate (memberikan pelayanan dalam upaya pembinaan dan pemberdayaan komunitas adat), empowerment (agen atau pelaku yang menggali dan mengembangkan potensi yang ada pada komunitas adat), social planner (pembinaan dan pemberdayaan komunitas adat meliputi mendampingi dalam penyusunan rencana program, menganalisa kebutuhan, merumuskan tujuan, pelaksanaan program dan evaluasi kegiatan), dan enabler (memberikan kemungkinan kepada komunitas adat untuk mendapatkan sistem pelayanan sosial agar mereka mengetahui dan mengakses sistem pelayanan tersebut).

Peneliti ini bertujuan untuk memahami ketahanan sosial yang meliputi aspek dari kemampuan pemecahan masalah, kemampuan adapatasi sosial, dan kemampuan bertransformasi atau partisipasi masyarakat Komunitas Adat Jalawastu terhadap perubahan sosial di yang kian berkembang di Desa Ciseureuh Kecamatan Ketanggungan Kabupaten Brebes.

Pekerjaan Sosial memiliki ranah terkait dengan pemberdayaan KAT dalam upaya meningkatkan dan mengembangkan potensi, kemampuannya serta sistem sumber yang tersedia. Peranan-peranan dan praktik pekerjaan sosial dapat dilakukan untuk meningkatkan kesejahteraan sosial di Komunitas Adat Jalawastu.

\section{METODE}

Penelitan ini dilakukan pada JanuariJuni 2021, dengan metode penelitian yang digunakan pada penelitian ini adalah penelitian kualitatif dengan pendekatan deskriptif. Menurut Moleong (2016:6) penelitian kualitatif adalah penelitian yang bermaksud untuk memahami fenomena tentang apa yang dialmi subyek penelitian misalnya, perliaku, 
persepsi, motivasi, tindakan dll. secara holistik dan dengan cara deskripsi dalam bentuk katakata dan bahasa pada suatu konteks khusus yang alamiah dan dengan memanfaatkan berbagai metode ilmiah.

Komunitas adat Jalawastu terletak di Desa Cisereuh Kecamatan Ketanggungan Kabupaten Brebes Provinsi Jawa Tengah dengan luas \pm 103 ha, wilayah komunitas adat Jalawastu terdiri dari hutan lindung atau hutan adat, sawah, kebun dan juga perkampungan atau pemukiman warganya. Sebagian besar wilayah di komunitas adat Jalawastu adalah hutan adat yaitu seluas \pm 64 ha, yang meliputi wilayah di Gunung Kumbang. Sementara untuk pemukiman masyarakat di Komunitas Adat Jalawastu cenderung mengumpul namun ada juga beberapa masyarakat yang tinggal jauh di perbatasan hutan adat.

Komunitas Adat Jalawastu terletak diatas 500-1000 mdpl hal tersebut menjadikkan wilayah kampung adat Jalawastu menjadi wilayah yang produktif untuk persawahan, dan juga perkebunan masyarakat. Sebagian besar masyarakat Jalawastu menanam tanaman padi dan juga jagung yang merupakan makanan pokok mereka, serta beberapa sayur mayur dan juga buah buahan untuk dijual. Selain bertani beberapa masyarakat di Jalawastu juga beternak sapi dan juga kambing serta mencari kayu bakar dan berbagai kebutuhan lainnya di hutan.

Berdasarkan data Desa Cisereuh Tahun 2021, komunitas adat Jalawastu memiliki 160 Kepala Keluarga dengan jumlah total masyarakatnya adalah 296 jiwa. Jumlah rumah yang ada di Komunitas adat Jalawastu hanya terdapat 111 Rumah. Masyarakat di Komunitas adat Jalawastu sebagian besar berjenis kelamin perempuan dengan jumlah 146 orang serta terdapat 150 orang masyarakat yang berjenis kelami laki-laki. Pendidikan masyarakat Jalawastu sebagian besar adalah tamat SD dan
SMP. Masyarakat Komunitas Adat Jalawastu memiliki tingkat pendidikan yang rendah, dan masih belum memiliki kesadaran yang tinggi akan pendidikan. Hal ini terjadi dikarenakan, hampir sebagian besar masyarakat Jalawastu memiliki mata pencaharian sebagai seorang petani, yang mana masyarakat Jalawastu menganggap pendidikan masih belum terlalu dibutuhkan bagi seorang yang bekerja sebagai petani.

Berdasarkan mata pencaharian masyarakat kondisi ekonomi masyarakat adat Jalawastu sebagian besar berada dalam kondisi ekomoni menengah ke bawah. Penghasilan masyarakat yang hanya mengandalkan pertanian dan juga peternakan serta hasil hutan, membuat masyarakat di komunitas adat Jalawastu memiliki penghasilan yang rendah. Masyarakat di Komunitas adat Jalawastu menggunakan hasil pertanian yang mereka tanam untuk memenuhi kebutuhan hidup dan sebagai makanan pokok sehari-hari.

Melalui pendekatan kualitatif peneliti menjadi instrumen atau alat penelitian. Penelitian kualitatif itu sendiri yaitu prosedur yang menghasilkan data deskriptif yang berupa kata-kata tertulis atau lisan dari orang-orang dan perilaku yang diamati secara menyeluruh dengan menggunakan metode ilmiah. Dengan aspek dari ketahanan sosial sebagai berikut:

a. Kemampuan Pemecahan Masalah (Coping capacities) yaitu mengukur bagaimana seseorang mengatasi dan pulih dari ancaman secepatnya dengan sumberdaya yang tersedia. Dasar rasional di balik coping adalah pemulihan dari level saat ini setelah terjadi peristiwa kritis.

b. Kemampuan Adapatasi (Adaptive capacities) kemampuan preventive, yaitu kemampuan belajar dari pengalaman masa lalu, mengantisipasi risiko di masa mendatang. Adaptasi diarahkan pada perubahan sosial yang meningkat, dan 
berfungsi untuk mengamankan kondisi pada saat ini dalam menghadapi risiko di masa depan.

c. Kemampuan Bertransformasi atau berpartisipasi (transformative capacities atau participative capacities), mencakup kemampuan seseorang untuk mengakses aset dan bantuan dari arena sosial-politik yang lebih luas, yaitu dari organisasi pemerintah dan masyarakat, untuk berpartisipasi dalam proses pengambilan keputusan, untuk meningkatkan kesejahteraan individual mereka dan mendorong ketahanan masyarakat terhadap perubahan sosial di masa yang akan datang.

Sumber data penelitian ini menggunakan sumber data primer dan sekunder. Penentuan sumber data primer (informan) dilakukan secara purposive, terhadap lima informan yakni kepada Kepala Desa Ciseureuh, Kepala Adat Jalawastu, Jagabaya (pemuda keamanan desa), Dewan Kokolot (tokoh yang dituakan) dan RT di Komunitas Adat. Sumber data sekunder meliputi profil desa, dokumentasi penelitian yang mendukung dan rekaman suara proses wawancara.

Teknik pengumpulan data yang digunakan adalah wawancara mendalam, observasi partisipatif dan studi dokumentasi. Pemerikasaan keabsahan data dilakukan untuk memperoleh data yang dapat dipertanggungjawabkan keabsahannya. Teknik pemeriksaan keabasahan data yang dilakukan dengan uji kredibilitas, uji keteralihan, uji kebergantungan data, dan uji kepastian data. Teknik analisis data menggunakan reduksi data, penarikan kesimpulan dan penyajian data.

\section{HASIL PENELITIAN}

Nilai adat dan budaya yang masih dipelihara oleh komunitas adat Jalawastu, membuat nilai-nilai sosial disana sangat tinggi, kehidupan yang saling menghargai dan menghormati seperti halnya gotong royong, saling membantu apabila tetangga kekurangan masih sangat terlihat di komunitas adat Jalawastu.

Tradisi adat yang masih dipertahankan antara lain berupa larangan atau pantangan segi bangunan (tidak diperbolehkan menggunakan bahan yang berasal dari semen, bata, genteng, dan juga keramik. Bahan bangunan rumah yang digunakan masyarakat berasal dari alam yaitu berupa kayu dan alang-alang.), dari segi pertanian (tidak diperbolehkan untuk menanam tanaman bawang merah, kacang tanah, kacang hitam, dan juga kedelai), dari segi kesenian (tidak diperbolehkan untuk mengadakan kesenian wayang, nabuh/membunyikan gong) dan segi perternakan (tidak diperbolehkan untuk memelihara kerbau, domba, ikan emas dan juga angsa).

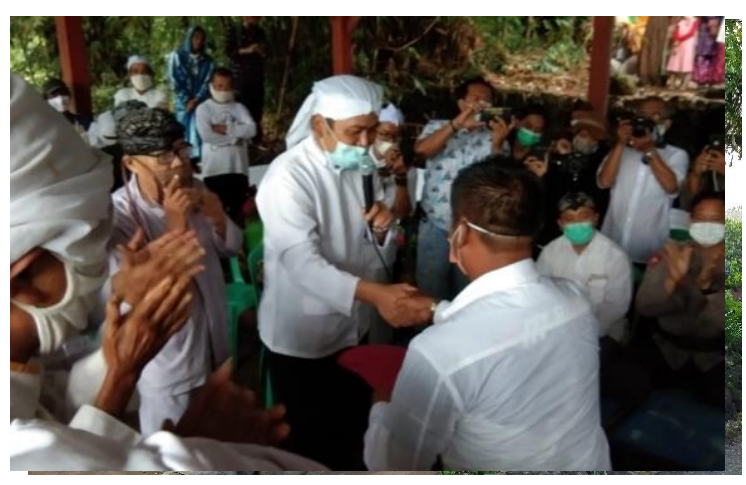

Gambar 1: Bangunan Rumah di Komunitas Adat Jalawastu

Di Jalawastu terdapat beberapa upacara adat dan juga tradisi yang hingga sekarang masih tetap dilestarikan diantaranya: (1) Ngasa yaitu upacara adat yang dilaksanakan pada hari Selasa Kliwon di mangsa kasanga dan dilaksanakan satu kali dalam satu tahun yang bertempat di Pesarean Gedong Jalawastu, upacara ini merupakan bentuk rasa syukur masyarakat kepada sang pencipta atas segala keberkahan yang telah diberikan. (2) Tundan yaitu upacara adat untuk mengusir hama tikus yang dilaksanakan apabila hama tikus mulai 
menyerang dan merusak hasil pertanian masyarakat. (3) Babarit, upacara adat yang dilaksanakan pada hari Selasa Kliwon yang bertujuan untuk menjaga kerukunan masyarakat. (4) Sedekah Bumi adalah upacara adat sebagai bentuk rasa syukur atas hasil pertanian dan juga kemakmuran yang dilaksanakan pada sabtu manis bulan hapit. (5) Tutulak adalah upacara adat yang bertujuan untuk tolak bala atau menangkal bahaya bagi masyarakat di wilayah komunitas adat Jalawastu. (6) Cako yaitu upacara adat yang dilakukan setelah tanam padi, yang bertujuan agar tanaman padi yang di tanam tumbuh dengan subur dan menghasilkan panen yang melimpah. (7) Ngaguyang Kuwu merupakan upacara adat untuk meminta hujan jika musim hujan tak kunjung tiba. (8) Tong-tong Breng merupakan upacara adat yang dilakukan sebagai upaya untuk mencari orang yang hilang di sekitar wilayah Komunitas Adat Jalawastu.

\section{Kemapuan Pemecahan Masalah}

Ketahanan sosial dalam bentuk pemecahan masalah terhadap perubahan sosial yang peneliti teliti dan dalami dari kelima informan yang tiga diantaranya merupakan perangkat adat yang meliputi ketua adat, wakil ketua adat dan ketua Jagabaya, sedangkan dua informan lainnya merupakan unsur pemerintahan yang meliputi Kepala Desa Ciseureh dan ketua RT 01 Dusun Jalawastu.

Pemecahan masalah yang umumnya dilakukan, meliputi upaya pembangunan, dalam mengatasi konflik dan mempersiapkan tradisi adat Jalawastu yang akan dilakukan. Dalam upaya penyelesaian masalah tersebut pada umumnya penyelesaian masalah yang ada di Jalawastu menggunakan musyawarah dan peraturan adat, seperti yang disampaikan oleh informan $\mathrm{K}$.

Hal tersebut menandakan kalau pemecahan masalah yang dilakukan oleh masyarakat Jalawastu pada umumnya masih mempertahankan nilai adat dengan melakukan musyawarah dengan pengurus adat dan masyarakat. Selain itu, masyarakat Jalawastu juga menjunjung tinggi rasa kekeluargaan dalam menjalani kehidupan sehari-hari, dan selalu menyelesaikan masalah dengan bermusyawarah. Hal ini, juga sesuai dengan apa yang disampaikan oleh $\mathrm{G}$ juga menjelaskan kalau penyelesaian konflik didusun Jalawastu pada umumnya dilakukan dengan cara mediasi dengan kekeluargaan.

Dalam hal ini $G$ menjelaskan terkait konflik sosial yang umumnya dirasakan ketika perbedan pemilihan umum, khususnya saat pemilihan kepala desa (Kuwu). Namun, dalam konflik tersebut tidak sampai berkepanjangan. Setelah pemilihan umum selesai, konflik perbedaan pilihan tersebut juga mereda. Konflik ini juga didasarkan karena tingginya rasa solidaritas dari masyarakat Jalawastu ketika ada calon kepala desa yang berasal dari Komunitas Adat Jalawastu, bersaing dengan calon kelapa desa dari dusun yang lain. Namun, sejauh konflik tersebut tidak pernah berkepanjangan dan tidak pernah juga sama dibawa ke ranah hukum. Seperti yang disampaikan oleh DN bahwa penyelesaiakan konflik belum sampai diselesaikan hingga mediasi ke ranah pemerintah desa, melainkan dapat di selesiakan secara adat dan kekeluargaan dengan melibatkan unsur masyarakat yang ada di Komunitas Adat Jalawastu. Sedangkan R dan D menjelaskan kalau komunitas Jalawastu selain dengan musyawarah juga masih menjunjung tinggi rasa gotong royong dalam melakukan kegiatan kehidupan bermasyakat, berikut penjelasan dari R:

"Disini masih tinggi juga gotong
royongnya rasa keluargannya,
kepeduliannya, dan untuk melakukan
pemecahan masalah biasanya yaa
dilakukan dengan cara musyawarah.


Kalaupun terkait dengan perselisih yaa pernah ada, tapi yaa udah sangat jarang juga. Kalaupun ada yaa diselesaikan secara kekeluargaan, dan ngga sampe lama masalahnya."

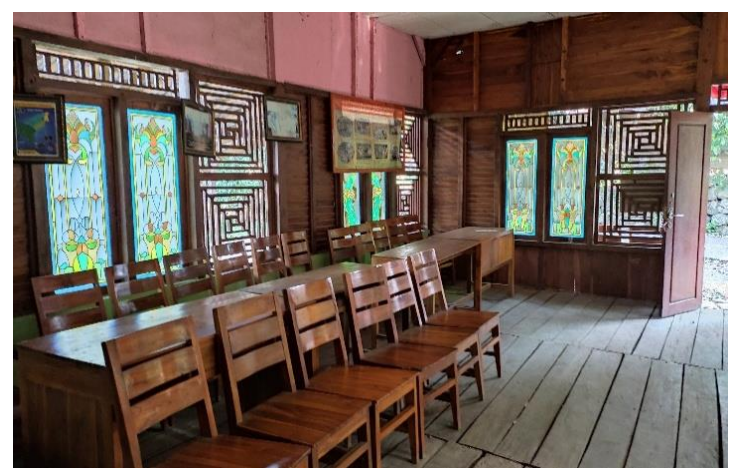

Gambar 3: Balai Budaya Komunitas Adat Jalawastu tempat Musyawarah

Hal dijelaskan oleh $\mathrm{R}$ bahwa kehidupan masyarakat yang ada di Komunitas Adat Jalawastu juga masih menjunjung tinggi rasa kekeluargaan dan gotong royong didalamnya. Hal ini, juga selaras dengan yang disampaikan oleh D mengemukaan:

"Disini juga masih gotong royong kalo mau bangun rumah kalau, atau mau hajatan, langsung ngga perlu pake undangan yang kertas gitu. Masyakarak sekitar tinggal dikasih tau kapan waktunya, langsung pada dateng ke rumah itu mas. Iyaa kalau hajatan yaa dibantu masak-masak. Kalo bikin rumah yaa dibantu juga sampe selesai, pada dateng bantu semua."

Pemecahan masalah yang dilakukan oleh masyakat Jalawastu juga melalui gotong royong dalam menjalankan aktivitas kehidupan bermasyarakat. Pernyataan tersebut sesuai dengan hasil observasi yang peneliti lakukan terhadap selama tinggal berdampingan dengan informan $\mathrm{R}$ dan informan $\mathrm{D}$, yang selalu menunjukan sikap yang hangat dan menyambut peneliti seperti layaknya keluarga, yang ditandai dengan selalu suguhkan makanan, dan hasil perkebunan selama proses penelitian.

Kegiatan musyawarah sendiri umumnya dilakukan pada saat malam hari dan dilakukan dibalai budaya, yang mana berdasarkan obervasi peniliti balai budaya disini juga umumnya digunakan juga sebagai sarana menginap bagi tamu dari luar yang singgah beberapa hari di Jalawastu untuk kepentingan tertentu.

\section{Kemapuan Adaptasi}

Kemampuan ketahanan sosial kedua yang diteliti dari masyarakat Komunitas Adat Jalawaastu di Desa Ciseureuh yaitu mengenai adaptasi sosial terhadap perubahan sosial. Adaptasi sosial merupakan penyesuaian yang dilakukan oleh masyarakat Komunitas Adat Jalawastu dalam menghadapi perubahan sosial yang saat ini sedang terjadi. Komunitas Adat Jalawastu berada di Desa Ciseureuh Kecamatan Ketanggungan, yang mana terkait dengan perubahan sosial sudah mulai terasa seiring perkembanganya zaman. Salah satunya di Komunitas Adat Jalawastu, yang dikenal masih mempertahankan nila-nilai peraturan adatnya secara turun temurun.

Adaptasi sosial Komunitas Adat Jalawastu terhadap perubahan sosial memiliki proses penyesuaian yang memiliki tahapan perkembangan. Masyarakat melakukan adaptasi sosial terkait dengan perubahan sosial khususnya perkembangan dari teknologi dan informasi seperti yang dijelaskan bahwa pengaruh globalisasi pun sudah masuk di wilayah Jalawastu, dengan syarat tetap nilainilai dan adat istiadat yang diwarisi secara turun temurun. Perkembangan perubahan sosial di Jalawastu juga dapat dirasakan oleh masyarakat Jalawastu, hal ini juga sesuai dengan yang disampaikan informan $G$ yang menyatakan kalau terkait dengan salah satu perubahan sosial yang telah masuk di Dusun 
Jalawastu ialah terkait dengan pembangunan infrastruktur yang awalnya masih sangat sederhana saat ini sudah berkembang di Komunitas Adat Jalawastu. Perkembangan transportasi dan telekomunikasi juga sudah mulai masuk juga di Komunitas Adat di Jalawastu. Hanya saja perubahan sosial tersebut hanya dapat diakses oleh kalangan remaja yang memahami terkait perubahan tersebut. Informan $\mathrm{G}$ menambahkan terkait dengan meskipun terkait dengan perubahan sosial yang mulai berkembang di

Komunitas Adat Jalawastu, namun terkait dengan nilai Adat yang ada di Jalawastu masih tetap dipertahankan. Perubahan sosial tetap diterima baik oleh masyarakat Jalawastu selama tidak bertentangan dengan nilai-nilai yang telah di wariskan secara turun temurun.

Informan $\mathrm{R}$ menjelaskan terkait dengan nilai adat di Jalawastu masih dijaga dengan baik oleh semua kalangan. Informan $\mathrm{R}$ juga menyatakan kalau masih banyak masyarakat yang belum dapat menggunakan teknologi meskipun telah masuk di Jalawastu. Mengingat hampir sebagaian bersar masyarakat yang ada di Jalawastu sudah menginjak dewasa hingga lanjut usia. Terkait dengan kemajuan teknologi yang sudah mulai masuk di Jalawastu, selama hal tersebut tidak melanggar peraturan adat yang diwariskan secara turun-temurun hal tersebut diperbolehkan.

Informan DN menjelaskan terkait dengan adaptasi sosial terhadap perubahan sosial yang ada di komunitas adat Jalawastu terkait dengan mempertahankan peraturan adat, khususnya dalam nilai-nilai kehidupan bermasyarakat, pantangan disegi bangunan, pertanian, pertenakan dan tradisi adat dan budayanya yang masih dilestarikan hingga sekarang. Itu yang menjadi perbedaan dengan dusun lain yang ada di Desa Ciseureuh, yang notabenenya sudah sama dengan kehidupan masyarakat pada umumnya di Indonesia.
Masyarakat Jalawastu yang tidak menginginkan tinggal di komunitas Adat Jalawastu juga dipersilahkan, dengan pindah di dusun lain. Seperti yang disampaikan oleh informan D yang menyatakan:

"Iyaa semuanya masyakarat yang tinggal di Jalawastu ya wajib menjunjung tinggi nilai adat yang berlaku. Kalo engga mau mempertahankan yaa bisa silahkan pindah di dusun lain. Terkait dengan perubahan sosial yang masuk di Jalawastu kaya HP, motor masih diizinkan selama dalam penggunaanya ngga melanggar nilai dan norma yang berlaku di Jalawastu."

Informan D menjelaskan selama masyarakat tinggal di wilayah jalawastu harus mengikuti nilai dan norma yang berlaku di masyarakat. Bilamana dari masyarakat yang menginginkan untuk hidup dengan tidak terikat oleh peraturan adat, maka dapat pindah ke dusun lain di wilayah Desa Ciseureuh.

Berdasarakan informasi yang didapatkan adaptasi yang dilakukan terhadap perubahan sosial yang terjadi di Komunitas Adat Jalawastu dengan mempertahankan nilai-nilai yang berupa langan dan pantangan serta dapat melestarikan tradisi adat yang sudah diwariskan secara turun-temurun. Terkait dengan perubahan sosial yang masuk di Komunitas Adat Jalawastu diperbolehkan dan manfaatnya dapat digunakan oleh masyarakat sekitar, selama tidak menyalahi ketentuan adat yang berlaku di masyarakat.

Berdasarkan yang disampaikan oleh informan D perihal masyarakat yang tidak menginginkan untuk tetap terus terikat dengan peraturan adat, mereka dapat pindah di dusun lain di Desa Ciseureuh. Berdasarkan obeservasi yang dilakukan oleh peneliti dalam melakukan aktivitas dengan masyarakat, sebagian yang tinggal di Komunitas Adat Jalawastu adalah 
orang tua dan anak anak remaja ke bawah. Untuk yang remaja di Jalawastu sebagian juga sudah memegang gadget yang digunakan dalam kehidupan sehari hari, sedangkan orang tua lebih cenderung tidak menggunakan alat telekomunikasi dalam melakukan kegiatan sehari-hari. Menurut informan R dan D kurang lebih sekitar $60 \%$ pasangan yang menikah, pindah dusun dengan alasan menginginkan kehidupan yang tidak terikat oleh peraturan adat, seperti yang saat ini masih dipertahakan di Komunitas Adat Jalawastu.

\section{Kemapuan Transformasi/Partisipasi}

Bentuk kemampuan transformasi atau partisipasi Komunitas Adat Jalawastu yang dirasakan, salah satunya adalah dengan lebih mendapatkan perhatian dari pihak pemerintah. Komunitas Adat Jalawastu sendiri saat ini mendapatkan hak yang sama sebagai warga negara dalam upaya peningkatan kesejahateraan sosial melalui program bantuan sosial, seperti yang dinyatakan oleh DN:

"Terkait upaya meningkatkan

kesejahteraan sosial yaa dari bantuan pemerintah kaya PKH, BPNT, Bantuan covid dari Desa juga masyarakat mendapatkan. Bantuan BPJS yaa mereka juga punya, artinya memiliki hak yang sama sebagai warga negara gitu mas."

Dalam hal ini DN menjelaskan bahwa komunitas saat ini telah memiliki akses yang sama dalam menerima bantuan sosial sebagai upaya peningkatan kesejahteraan sosial dari pemerintah. Bantuan sosial tersebut juga berupa program PKH, BPNT, dan BLT yang dikelola oleh pemerintah.

Informan $\mathrm{G}$ menjelaskan dalam kemampuan transformasi dalam mengakses bantuan yang lebih luas, komunitas adat jalawastu juga mendapatkan hak yang sama sebagai warga negara. Selain itu, upaya perkembangan transformasi yang telah dilakukan adalah dengan telah diundangkannya
Peraturan Desa No. 1 Tahun 2016 terkait dengan Kampung Budaya Jalawastu yang mengatur terkait dengan tradisi dan adat di Komunitas Adat Jalawastu. Informan G juga menjelaskan terkait dengan pembangunan jalan akses menuju Jalawastu juga saat ini dalam upaya perbaikan. Saat ini komunitas Adat Jalawastu disini sudah mendapatkan Surat Keputusan (SK) Hutan Adat dari Presiden Republik Indonesia seperti yang disampaikan oleh informan $\mathrm{K}$ :

"Iyaa disini kemarin sudah mendapatkan SK dari presiden langsung mas terkait dengan hutan adat. Kemarin di bulan Januari 2021 dari kami mendapatkan SK tersebut untuk mengelola dan memanfaatkan hutan adat seluas 64 hektar, yang mana nantinya akan ditanamani benih durian, porang dll, yang nantinya akan dimanfaatkan juga untuk masyarakat Jalawastu."

Salah satu bentuk tranformasi yang dilakukan oleh masyarakat Jalawastu adalah lebih mendapatkan perhatian dari pemerintah untuk mempertahankan nilai adat dan tradisi, salah satunya dengan pemberian SK dari Presiden Indonesia pada Januari 2021 untuk masyarakat Jalawastu mengelola hutan adat, yang mana manfaat hutan adat tersebut dapat dikelola oleh masyarakat Jalawastu untuk upaya kesejahteraan sosial. Manfaat dari SK tersebut saat ini juga sudah mulai dapat dirasakan oleh masyarakat, seperti yang dijelaskan oleh informan R dan D. Informan R menyatakan:

"Setelah adanya SK dari presiden terakit hutan adat, ada program terkait dengan hutan rakyat. Kemarin saya dan Bapak Dadi selaku penyuluh dari Dinas Kehutanan Brebes melakukan penanaman bibit durian, kelapa porang, mangga di daerah hutan adat, untuk melakukan penghijauan. Saat ini dengan Bapak Dadi 
juga sedang mencanangkan kegiatan ternak klanceng (madu hitam) yang melibatkan kelompok usaha dari masyarakat Jalawastu."

Setelah mendapatkan SK dari Presiden terkait dengan hutan adat, masyarakat lebih diperhatikan dalam sektor kehutanan. Saat ini dari Dinas Ketuhanan Brebes selalu melakukan kunjungan rutin untuk membantu masyarakat Jalawastu dalam mengelola hutan adat diwilayah Jalawastu. Salah satu upaya yang dilakukan dari pihak pemerintah Daerah Kabupaten Brebes disini adalah dengan melakukan penaman bibit buat dilahan Hutan Adat Jalawastu, yang mana manfaat dari hutan tersebut nantinya dapat dimanfaatkan oleh masyarakat Jalawastu. Selain itu, dari pihak Dinas Perhutanan Kabupaten Brebes melakukan pemberdayaan dengan memanfaatkan kearifan lokal Jalawastu dengan membuat kelompok usaha masyarakat dalam berternak madu alam (Klanceng).

Kemampuan transformasi/partisipasi yang saat ini sedang diupayakan adalah dengan membangun kelompok usaha bersama berternak madu yang diinisiasi oleh Dinas Perhutanan Kabupaten Brebes. Informan D menjelaskan kegiatan tersebut baru dilaksankan tiga bulan yang lalu, sehingga partisipasi masyakat dalam bertenak madu belum masih beberapa warga saja yang berkolaborasi.

Selain itu, bentuk transformasi atau partisipasi yang telah dilakukan oleh masyarakat Jalawastu antara lain dengan lebih meningkatkan koordinasi dengan pihak desa dan kembali mengaktifkan kegiatan organisasi kelompok tani. Seperti dijelaskan terkait dengan hubungan yang baik antara pemerintah desa dengan pengurus adat, khususnya dalam alur koordinasi dalam mempertahankan nilai dan mempersiapkan tradisi adat yang akan dilakukan. Selain itu, beberapa oraganiasi yang mulai aktif kembali juga salah satunya adalah kelompok tani. Seperti yang disampaikan oleh informan D selaku ketua RT yang menyatakan. "Terkait dengan poktan juga sekarang aktif kembali ya baru baru ini awal 2021, kemarin dapet bantuan traktor 2 buat kepentingan pertanian masyarakat sini." Kelompok tani yang ada didusun Jalawastu sudah mulai aktif kembali dan salah satu manfaatnya mendapatkan bantuan sarana pertanian yang dapat digunakan oleh masyarakat Jalawastu yang membutuhkan.

Dalam hal ini terkait dengan bentuk kemapuan tranformasi/partisipasi masyarakat seperti yang disampaikan oleh infroman DN dan G, untuk mengakses aset dan bantuan dari arena sosial-politik yang lebih luas, yaitu dari organisasi pemerintah dan masyarakat, berbentuk dengan mendapatkannya masyarakat Komunitas Adat Jalawastu dalam upaya peningkatan kesejahteraan sosial melalui bantuan sosial, sebagaimana mendapatkan hak sebagai warga negara. Selain itu, dengan keikutsertaan pemerintah desa dalam upaya pembanguan secara fisik, salah satunya adalah akses jalan dan listrik di komunitas Adat Jalawastu dan diundangkannya peraturan regulasi terkait dengan kampung budaya Jalawastu yang menentapkan secara tertulis peraturan adat komunitas adat Jalawastu.

Berdasarkan hasil studi observasi yang dilakukan oleh peneliti, kegiatan menanam benih porang dan berternak madu pun sudah dilakukan oleh informan $\mathrm{R}$ dan Informan $\mathrm{D}$ sebagai salah satu upaya kegiatan transformasi yang dilakukan.

\section{PEMBAHASAN}

Pada bagian ini peneliti melakukan analisis hasil penelitian terkait Ketahanan Sosial Komunitas Adat Jalawastu terhadap Perubahan Sosial. Analisis data dilakukan pada saat pengumpulan data berlangsung dan setelah 
selesai pengumpulan data dalam periode tertentu. Aktivitas dalam penelitian kualitatif ini dilakukan secara interaktif dan berlangsung secara terus-menerus sampai tuntas sehingga datanya sudah jenuh. Ketahanan sosial yang diteliti dan dianalisis yaitu terdiri dari bentuk ketahanan sosial dan strategi ketahanan sosial sesuai dengan kajian teori yang mendasari mengenai dasar-dasar ketahanan sosial dan bentuk ketahanan sosial.

Secara umum ketahanan sosial yang terdiri dari tiga aspek tersebut yang meliputi pemecahan masalah, adaptasi dan transformasi sosial yang dimiliki oleh masyarakat Komunitas Adat Jalawastu. Adanya fakta-fakta empiris di lapangan yang membuktikan kondisi dari ketahanan sosial itu yang dapat dijadikan indikator lainnya dalam menilai baik atau buruk ketahanan sosial yang ada pada Komunitas Adat Jalawastu di Desa Ciseureuh Kecamatan Ketanggungan Kabupaten Brebes, antara lain sebagai berikut:

\section{Ketahanan Sosial terkait Kemampuan Pemecahan Masalah}

Menurut Betke dalam Marwanti, dkk (2017:284) merupakan suatu proses dimana kemampuan komunitas untuk menghidari atau mengelola konflik dan upaya menemukan solusi, seiring dengan perkembangan komunitas itu sendiri. Dalam hal ini ketahanan yang dimaksudkan merupakan suatu bentuk kemampuan utuk mengatasi masalah dalam menghadapi perubahan sosial dalam kehidupannya. Berdasarkan hasil analisis dapat diketahui bahwa, hasil penelitian afirmatif terhadap konsep tersebut. Hasil penelitian menjelaskan bahwa didalam komponen kehidupan masyarakat Komunitas Adat Jalawastu ini memiliki ketahanan sosial dalam aspek pemecahan masalah. Masyarakat Jalawastu masih menjunjung tinggi nilai dan adat yang dilakukan secara turun temurun dengan membangun komunikasi dengan pengurus adat. Sedangkan untuk melakukan pemecahan masalah untuk kepentingan masyarakat, selalu dilakukan dengan musyawarah di Komunitas Adat Jalawastu. Kemampuan pemacahan masalah melalui keluargaan, dan musyawarah ini masih dilakukan di Komunitas Adat Jalawstu, meski telah mengalami perkembangan zaman dan perubahan sosial dari waktu ke waktu.

Menurut Leitch dalam Agus Suwigyo dan Rhoma D.A.Y (2018:96) menjelaskan ketahanan sosial secara konseptual didefinisikan sebagai kemampuan individu dan kelompok untuk secara tepat waktu bertindak ketika keadaan stabil dan mengatur diri serta tetap aktif terlibat dalam merespons kondisi yang tak menentu. Konsep tersebut mengandung dimensi pokok, salah satunya adalah kemampuan atau kapasitas untuk mengidentifikasi dan mengelola permasalahanan (coping capacities). Hasil analisis mengenai bentuk ketahanan sosial ini memperlihatkan bahwa hasil penelitian afirmatif terhadap konsep tersebut. Masyarakat Komunitas Adat Jalawastu masih memiliki kemampuan pemecahan masalah yang baik, melalui komunikasi yang baik dalam bentuk kepedulian, rasa gotong royong dan pemecahan masalah musyarawah serta masih menjunjung tinggi nilai dan adat yang berlaku dimasyarakat sebagai metode pemecahan masalah dalam dinamika kehidupan bermasyarakat sekaligus untuk merespon perubahan sosial yang terjadi di komunitas Adat Jalawastu.

Menurut Marcus Keck (2013:10) salah satu bentuk aspek dari ketahanan sosial adalah kemapuan terkait dengan kemampuan pemecahan masalah dalam menghadapi perubahan sosial. Berdasarkan hasil analisis dapat diketahui bahwa hasil penelitian mengenai pemecahan masalah Komunitas Adat Jalawastu di Desa Ciseureuh dapat dijabarkan sebagai berikut: 


\section{a. Bentuk Pemecahan Masalah}

Menurut Nurul Hidayah (2017:162) Coping capacities menunjukkan respon reaktif (ex-post) dan absorptive, yaitu mengukur bagaimana seseorang mengatasi dan pulih dari ancaman secepatnya dengan sumberdaya yang tersedia. Berdasarkan hasil analisis aspek ketahanan sosial berupa pemecahan masalah dapat diketahui bahwa hasil penelitian afirmatif terhadap konsep unsur ketahanan sosial tersebut. Hasil penelitian menemukan adanya fenomena di lapangan yang mengungkapkan pemecahan masalah ini diwujudkan dengan cara kekeluargaan dalam menghadapi konflik, melalui mediasi dengan beberapa pihak dari pengurus adat, melalui musyawarah dalam menyelesaikan atau mempersiapkan sesuatu dan masih menjujung tinggi gotong royong dalam menjalankan kehidupan bermasyarakat. Bentuk masalah yang terjadi dimasyarakat Jalawastu umumnya terkait dengan perselisihan yang sifatnya jarang terjadi. Hal ini terjadi umumnya karena perbedaan pemilihan kepala desa. Namun, persilihan tersebut tidak menjadi masalah yang berlarut-larut terjadi dimasyarakat. Suasana akan kembali normal bila situasi tersebut sudah terlewati.

\section{b. Strategi Pemecahan Masalah}

Menurut Nurul Hidayah (2017:162) kemampuan pemecahan masalah ini melibatkan kemampuan taktis dari masyarakat dan mengatasi masalah dalam jangka pendek untuk menghadapi perubahan sosial. Berdasarkan hasil analisis aspek ketahanan sosial berupa pemecahan masalah dapat diketahui bahwa hasil penelitian afirmatif terhadap konsep unsur ketahanan sosial tersebut. Hasil penelitian menemukan adanya strategi di dalam lingkup Komunitas Adat Jalawastu dalam upaya pemecahan masalah. Strategi pemecahan masalah yang digunakan oleh masyarakat Jalawastu dalam menyelesaikan masalah adalah dengan cara mempertahan nilai-nilai adat dalam menjalakan kehidupan sehari-hari dan musyawarah untuk mendiskusikan kegaiatan masyarakat yang akan dilakukan baik yang bersifat pembangunan maupun mempersiapkan tradisi yang akan dilakukan serta menjunjung tinggi rasa kekeluargan dalam menyelesaikan persilisihan yang terjadi dimasyarakat.

\section{c. Pelaksanaan Pemecahan Masalah}

Menurut Nurul Hidayah (2017:162) Coping capacities menunjukkan respon reaktif dan absorptive, yaitu mengukur bagaimana seseorang mengatasi dan pulih dari ancaman secepatnya dengan sumberdaya yang tersedia. Berdasarkan hasil analisis aspek ketahanan sosial berupa pemecahan masalah dapat diketahui bahwa hasil penelitian afirmatif terhadap konsep unsur ketahanan sosial tersebut. Pemecahan masalah di Komunitas Adat Jalawastu masih menggunakan nilai-nilai adat, yang mana dalam perumusan masalah dan pengambilan keputusan harus sesuai dengan peraturan adat dan harus melibatkan pengurus adat seperti dewan kokolot, kuncen dan pertimbangan masyarakat pada umumnya. Selain itu, masyarakat juga memanfaatkan Balai Budaya sebagai tempat pertemuan warga untuk melakukan musyawarah, yang biasanya dilakukan pada saat malam hari.

\section{Ketahanan Sosial terkait Kemampuan Adaptasi}

Menurut Muhamad Fakhry (2016:234) Ketahanan sosial merupakan sebuah respons adaptif suatu masyarakat terhadap berbagai macam ancaman yang diaktualisasikan melalui beberapa proses, yaitu salah satunya kemampuan masyarakat untuk dapat mengatasi berbagai macam perubahan sosial. Berdasarkan hasil analisis dapat diketahui bahwa hasil penelitian afirmatif terhadap konsep tersebut. Hasil penelitian menjelaskan bahwa didalam komponen kehidupan masyarakat Komunitas Adat Jalawastu ini 
memiliki ketahanan sosial dalam aspek adaptasi sosial. Akan tetapi ketahanan sosial yang dimiliki oleh Komunitas Adat Jalawastu ini memerlukan upaya penyesuaian terhadap perubahan sosial yang terjadi saat ini.

Secara keseluruhan terkait dengan adaptasi sosial yang dilakukan masyakat Jalawastu terhadap perubahan sosial yang terjadi sudah baik. Masyarakat tetap mempertahankan nilai adat yang mengatur kehidupan bermasyarakat, dengan tetap menerima perubahan sosial yang positif. Meskipun kondisi ketahanan sosial masyarakat Komunitas Adat Jalawastu pada saat ini perlu adanya penyesuaian dengan perkembangan zaman yang saat ini kian modern. Hal ini dikarenakan, perkembangan teknologi yang masuk belum sepenuhnya dapat diberdayakan oleh masyarakat Jalawastu, mengingat kertebatasan pemahaman masyarakat yang sebagian besar berada direntang usia dewasa akhir hingga lanjut usia, yang mana tidak mengikuti jalur perkembangan teknologi tersebut. Namun, sebagian masyarakat yang lainnya sudah mampu memanfaatkan perubahan sosial yang masuk, diantaranya perkembangan teknologi transportasi dan telekomunikasi yang dapat diakses oleh generasi muda untuk kepentingan mobilitas dan pendidikan.

Menurut Betke dalam Marwanti (2017:162) Ketahanan sosial menggambarkan kemampuan bertahan di sistem lokal dari arus globalisasi dan desentralisasi. Hasil analisis mengenai bentuk ketahanan sosial ini memperlihatkan bahwa hasil penelitian afirmatif terhadap konsep tersebut. Hasil penelitian menjelaskan bahwa didalam beraktifitas sehari-hari Komunitas Adat Jalawastu melakukan penyesuaian terhadap perubahan zaman khususnya dibidang transportasi dan kemjauan teknologi, dengan tetap melaksanakan sistem lokal yang ada, dalam hal ini adat dan tradisi yang diwarisi secara turun temurun sampai saat ini. Karena hal tersebut, Komunitas Adat Jalawastu memiliki kemapuan adapatasi dalam menghadapi perubahan sosial yang kian berkembang dengan tetap menjaga sistem lokal dalam menjalani kehidupan bermasyarakat.

Menurut Marcus Keck (2013:10) salah satu bentuk aspek dari ketahanan sosial adalah kemapuan terkait dengan adaptasi sosial dalam menghadapi perubahan sosial. Adaptasi sosial atau yang biasa dikenal dengan penyesuaian sosial setiap masyarakat di suatu wilayah memiliki karakterisitik yang beragam. Bagaimana masyarakat dapat menerima hal yang baru dan dapat menolak hal yang tidak sesuai dengan nilai dan norma yang berlaku. Berdasarkan analisis mengenai hasil penelitian mengenai adaptasi sosial Komunitas Adat Jalawastu di Desa Ciseureuh Kecamatan Ketanggungan Kabupaten Brebes dapat dijabarkan sebagai berikut:

\section{a. Bentuk Adaptasi}

Menurut Nurul Hidayah (2017:161) adaptasi diarahkan pada perubahan sosial yang meningkat, dan berfungsi untuk mengamankan kondisi pada saat ini dalam menghadapi risiko di masa depan. Berdasarkan hasil analisis aspek ketahanan sosial berupa adaptasi sosial dapat diketahui bahwa hasil penelitian afirmatif terhadap konsep unsur ketahanan sosial tersebut. Hasil penelitian menemukan adanya fenomena di lapangan yang mengungkapkan adaptasi sosial secara adat ini diwujudkan dengan bentuk adanya nilai-nilai adat yang menjadi pedoman tata kelakuan masyarakat yang paling tinggi kedudukannya karena bersifat kekal dan teintegrasi sangat kuat terhadap pola perilaku masyarakat yang memilikinya.

Komunitas Adat Jalawastu dengan mempertahankan nilai-nilai yang berupa larangan dan pantangan serta dapat 
melestarikan tradisi adat yang sudah diwariskan secara turun-temurun. Terkait dengan perubahan sosial yang masuk di Komunitas Adat Jalawastu diperbolehkan dan dapat dimanfaatkan oleh masyarakat sekitar, selama tidak menyalahi ketentuan adat yang berlaku di masyarakat. Dalam hal ini Komunitas Adat Jalawastu masih mempertahankan nilai-nilai adat ditengah perubahan sosial yang terjadi, namun, tidak menutup kemungkinan bentuk perubahan sosial sesuai dengan perkembangan zaman yang bermanfaat bagi masyarakat.

\section{b. Strategi Adaptasi}

Menurut Nurut Hidayah (2017:161) adaptive capacities merujuk pada kemampuan preventive, yaitu kemampuan belajar dari pengalaman masa lalu, mengantisipasi risiko di masa mendatang. Berdasarkan hasil analisis aspek ketahanan sosial berupa adaptasi sosial dapat diketahui bahwa hasil penelitian afirmatif terhadap konsep unsur ketahanan sosial tersebut. Hasil penelitian menemukan terdapat strategi di dalam lingkup Komunitas Ada Jalawastu dalam upaya adaptasi sosial. Hal tersebut ditunjukan dengan upaya-upaya yang dilakukan oleh Komunitas Adat Jalawastu dengan cara memanamkan nilai-nilai tradisi adat seperti pantangan dan larangan, sejerah, cerita rakyat yang ada di Jalawastu dan terkait dengan tempat-tempat keramat kepada anakanak sejak dini dan masyarakat pendatang yang baru di Jalawastu. Hal ini juga bertujuan agar generasi penerus dan masyarakat secara umum dapat mengetahui dan bejalar dari nilai-nilai yang diwarisi secara turun temurun dalam menjalani kehidupan masyarakat di masa sekarang dan yang akan datang.

Selain itu, Masyarakat juga saling mengingatkan apabila beberapa sikap dari masyarakat yang bertentangan dengan nilai adat. Upaya lain yang dilakukan saat ini yang dapat dilakukan adalah dengan cara melestarikan kesenian dan permaainan tradisional asli dari Komunitas Adat Jalawastu dan menampilkannya di tradisi ngasa yang dipentaskan setahun sekali atau dalam eventevent tertentu dari pemerintah setempat dan daerah. Hal ini bertujuan agar kearifan lokal yang ada di Jalawastu dapat selalu dilestarikan dan tidak tergerus oleh perkembangan zaman dan perubahan sosial yang terjadi.

\section{c. Pelaksanaan Adaptasi}

Menurut Nurul Hidayah (2017:161) kemampuan adaptasi juga harus melibatkan kemampuan strategis dan perencanaan jangka panjang dalam menghadapi perubahan sosial. Berdasarkan hasil analisis aspek ketahanan sosial berupa pemecahan masalah dapat diketahui bahwa hasil penelitian afirmatif terhadap konsep unsur ketahanan sosial tersebut. Hasil temuan dilapangan bahwa kemampuan adaptasi di Komunitas Adat Jalawastu terdahap perubahan sosial masih menunjukan nilai adat tradisional yang masih terjaga hingga samapi saat ini. Hal ini dapat terlihat dari bangunan fisik, peliharaan hewan ternak dan jenis tanaman pertanian yang di tumbuh wilayah Jalawastu masih terus diterapkan sesuai dengan peraturan adat. Perkembangan tekonologi seperti transportasi dan komunikasi sudah mulai masuk, hal ini tidak beperngaruh kepada peraturan adat secara umum yang berlaku di wilayah Komunitas Adat Jalawastu.

Namun, masuknya arus globalisasi tersebut belum dapat dimanfaatkan oleh semuanya masyarakat yanng tinggal di Komunitas Adat Jalawastu. Mengingat sebagian masyarakat di Jalawastu berusia dewasa akhir dan lanjut usia yang kurang memiliki daya tarik dan pemahaman terkait dengan teknologi. Dari perubahan sosial ini justru berdampak kepada pembentukan sikap dan pola pikir dari pemuda yang ada di Jalawastu. Hal ini mengakibatkan 
berkurangnya pemuda-pemudi diusia produkif yang berkeinginan untuk menetap dan tinggal di Jalawastu. Pemuda-pemudi yang ada di Jalawastu lebih memilih untuk merantau ke luar kota dan pindah ke dusun lain setelah menikah, dengan dalih supaya tidak terikat oleh peraturan adat.

\section{Ketahanan Sosial terkiat Kemampuan Transformasi/Partisipasi}

Menurut Daud Bahransyaf dan Ratih Probosiwi (2013:226) mengemukakan ketahanan sosial merupakan suatu konsep yang diperlukan oleh masyarakat untuk menjaga, melindungi dan mengembangkan perlindungan sosial, partisipasi masyarakat, pengendalian terhadap konflik dan mampu mengelola sumber daya alam dan sosial. Berdasarkan hasil analisis dapat diketahui bahwa, hasil penelitian afirmatif terhadap konsep tersebut. Hasil penelitian menjelaskan bahwa didalam komponen kehidupan masyarakat Komunitas Adat Jalawastu ini memiliki ketahanan sosial dalam aspek transformasi sosial. Adanya ketahanan sosial yang baik di dalam lingkungan Komunitas Adat Jalawastu, yang ditandai dengan masih terjaganya nilai adat tradisi yang dipertahankan, dan menerima perubahan-perubahan sosial yang positif yang dapat dimanfaatkan oleh masyarakat khususnya yang berkait dengan dengan peraturan regulasi, berkembangnya keorganisasian kemasyarakatan dan pengelolaan hutan adat serta sumber daya alam yang saat ini mulai dikelola oleh Masyarakat Jalawastu.

Menurut Rahayu dalam Prisia Kiki W (2020:254) masyarakat dapat dikatakan memiliki ketahanan sosial salah satunya dengan mampu memelihara kearifan lokal dalam mengelola sumber daya alam dan sosial. Hasil analisis mengenai bentuk ketahanan sosial ini memperlihatkan bahwa hasil penelitian afirmatif terhadap konsep tersebut.
Dalam hal ini upaya kemapuan transformasi sosial sedang tahap dilakukan oleh Komunitas Adat Jalawastu dalam menghadapi perubahan sosial yang terjadi, masyarakat Jalawastu sudah mengelola hutan adat yang mana nantinya hasil dari sumber daya alam tersebut dapat dimanfaatkan oleh masyarakat Jalawastu. Saat ini masyarakat Jalawastu juga diberdayakan untuk memaksimalkan potensi sumber daya, melalui pembentukan kelompok usaha bersama masyarakat. Dalam hal ini yang sedang berkembang berternak madu klanceng dan memanam porang di lahan pertanian yang dikelola oleh masyarakat Jalawastu. Kegiatan tersebut bernilai ekonomis yang dapat memberikan penghasilan tambahan bagi masyarakat Jalawastu, sekaligus memperkenalkan kearifan lokal dari Komunitas Adat Jalawastu kepada masyarakat luas.

Marcus Keck (2013:10) menjelaskan kemampuan transformasi sosial mencakup kemampuan seseorang untuk mengakses aset dan bantuan dari arena sosial-politik yang lebih luas, yaitu dari organisasi pemerintah dan masyarakat, untuk berpartisipasi dalam proses pengambilan keputusan, dan untuk meningkatkan kesejahteraan individual mereka dan mendorong ketahanan masyarakat terhadap perubahan sosial di masa yang akan datang, yang mana cara eksplisit menggabungkan topik perubahan progresif dan pembangunan. Berdasarkan hasil analisis dapat diketahui bahwa hasil penelitian mengenai transformasi sosial Komunitas Adat Jalawastu di Desa Ciseureuh dapat dijabarkan sebagai berikut:

\section{a. Bentuk Transformasi/Partisipasi}

Nurul Hidayah (2017:161) yang mengemukakan transformasi yang dilakukan merupakan upaya untuk mengakses aset dan bantuan dari area sosial politik yang lebih luas (masyarakat ataupun pemerintah) untuk 
meningkatkan kesejahteraan sosial masyarakat dan meningkatkan perubahan pembangunan yang progresif. Berdasarkan hasil analisis aspek ketahanan sosial berupa transformasi sosial dapat diketahui bahwa hasil penelitian afirmatif terhadap konsep unsur ketahanan sosial tersebut. Hasil penelitian menemukan adanya fenomena dilapangan menujukan adanya transformasi sosial secara adat ini diwujudkan dengan dikeluarkannya kebijakan dan regulasi Surat Keputusan (SK) terkait dengan hutan adat oleh presiden RI kepada Komunitas Adat Jalawastu. Melalui SK hutan adat, masyarakat Jalawastu lebih mendapatkan perhatian khusus mengenai sektor kehutanan dari pemerintah daerah kabupaten Brebes melalui Dinas Perhutanan kabupaten Brebes. Bentuk perhatian tersebut adalah dengan melakukan penanaman bibit buah-buahan yang nantinya akan dimanfaatkan oleh masyarakat Jalawastu dan pemberdayaan masyarakat melalui kelompok usaha bersama untuk beternak madu yang dikelola oleh masyarakat.

Bentuk yang lainnya dari kemampuan transformasi/partisipasi ditandai dengan meningkatkanya koordanasi dan kolaborasi yang ada di dusun Jalawastu dengan pemerintah desa, khususnya dalam mempertahankan nilai adat dan tradisi yang ada di Jalawastu. Hal ini terlihat dari sudah ditetapkannya peraturan desa yang mengatur kampung budaya Jalawastu dan selalu membangun koordinasi dalam melakukan kegiatan tradisi yang dilakukan di Jalawastu. Selain itu, beberapa organisasi kemasyarakat juga sudah mulai aktif kembali seperti kelompok tani Jalawastu, dimana berperan untuk membantu masyarakat Jalawastu dalam pemenuhan kebutuhan pertanian. Hal ini sangat bermanfaat, yang mana masyarakat Jalawastu mayoritas bermata-pencaharian sebagai seorang petani.

\section{b. Strategi Transformasi/Partisipasi}

Nurul Hidayah (2017:161) menjelaskan kemapuan transformasi yang dilakukan merupakan upaya untuk mengakses aset dan bantuan dari area sosial politik yang lebih luas, membutuhkan partisipasi atau ikutsertaan masyarakat dalam pengambilan keputusan dan untuk dapat meningkatkan kesejahteraan sosial masyarakat serta meningkatkan perubahan pembangunan yang progresif. Berdasarkan hasil analisis aspek ketahanan sosial berupa transformasi sosial dapat diketahui bahwa hasil penelitian afirmatif terhadap konsep unsur ketahanan sosial tersebut. Hasil penelitian menemukan adanya fenomena dilapangan menujukan adanya transformasi sosial secara adat ini diwujudkan melalui strategi yang dilakukan dengan cara merespon bantuan kesejahteraan sosial dengan baik, terutama dalam kegiatan yang saat ini sedang diprioritaskan yaitu memanfaatkan potensi hutan adat dan bergabung serta berpastisipatif aktif dalam merespon kegiatan kelompok usaha bersama berternak madu. Upaya peningkatan transformasi/partisipasi yang lainnya juga dilakukan dengan mengadvokasikan terkait dengan pembangunan fisik yang dibutuhkan oleh kepentingan umum masyarakat Jalawastu dan merespon secara positif pengembangan masyarakat yang dilakukan oleh pemerintah terhadap Komunitas Adat Jalawastu.

\section{c. Pelaksanaan Transformasi/Partisipasi}

Berdasarkan hasil analisis aspek ketahanan sosial berupa transformasi sosial menurut Marcus Keck (2013:10) yang mengemukan kemampuan masyarakat untuk dapat berpartisipasi dalam kegiatan pembangunan kesejahteraan sosial dan pembangunan kearah yang progresif, diketahui bahwa hasil penelitian afirmatif terhadap konsep unsur ketahanan sosial tersebut. Hasil penelitian menemukan adanya fenomena 
dilapangan menujukan adanya transformasi sosial, dengan pelaksanaan tranformasi/partisipasi di Komunitas Adat Jalawastu mulai dirasakan di tahun 2012an ke atas. Di Tahun 2012 keatas masyarakat di Komunitas Adat Jalawastu mulai diperhatikan terkait dengan segala upaya regulasi untuk mempertahankan nilai adat dan budaya, yang dilakukan oleh pemerintah desa, pemerintah daerah maupun pemerintah pusat. Selain itu pembangunan fisik terkait dengan akses masuk ke Jalawstu sudah mulai diperbaiki dan pada tahun 2021 ini, masyarakat Jalawastu mendapatkan pengembangan kapasitas dari Dinas Perhutanan Kabupaten Brebes untuk mengelola hutan adat yang terdapat di Komunitas Adat Jalawastu. Dalam hal ini Komunitas Adat Jalawastu berada pada proses menjalakan upaya transformasi/partisipasi untuk bergerak kearah yang lebih progresif.

Akan tetapi, masyarakat Jalawastu belum semuanya ikut serta dalam upaya kegiatan pembangunan kesejateraan sosial dan pembangunan ke arah yang lebih progresif dikarenakan minimnya pemahaman masyarakat dari untuk memaksimalkan potensi sumber yang tersedia di Jalawastu. Dampak dari perubahan sosial terhadap kemampuan transfomasi/partisipasi menyebabkan tingkat perpindahan penduduk yang tinggi dikarenakan masyarakat ingin dapat mengembangkan diri dan berkarir di luar Komunitas Adat Jalawastu. Selain itu, beberapa masyarakat yang masih tinggal di Jalawastu juga masih banyak yang belum ikut berpartisipasi dalam merespon perubahan transformasi/partisipasi yang saat ini mulai dilakukan dengan memanfaatkan potensi alam Komunitas Adat Jalawastu, yang didampingi oleh Dinas Perhutanan Daerah sebagai upaya pemberdayaan masyarakat.

\section{KESIMPULAN}

Penelitian ini memberikan pemahaman mengenai Ketahanan Sosial Komunitas Adat Jalawastu terhadap Perubahan Sosial di Desa Ciseureuh Kecamatan Ketanggungan Kabupaten Brebes. Berdasarkan hasil penelitian dapat disimpulkan bahwa ketahanan sosial masyarakat Komunitas Adat Jalawastu mampu bertahan menghadapi perubahan sosial. Indikator bertahannya ketahanan sosial masyarakat Komunitas Adat Jalawastu, dibuktikan dengan adanya nilai-nilai dan tradisi yang masih bertahan ditengah perubahan zaman yang kian berkembang.

Masyarakat Jalawastu memiliki kemampuan pemecahan masalah yang baik dalam melakukan ketahanan sosial. Bentuk kemapuan pemecahan masalah diwujudkan dengan cara kekeluargaan dalam menghadapi konflik, melalui mediasi dengan beberapa pihak dari pengurus adat, melalui musyawarah dalam menyelesaikan atau mempersiapkan kegiatan masyarakat dan masih menjujung tinggi gotong royong dalam menjalankan kehidupan bermasyarakat.

Masyarakat Komunitas Adat Jalawastu memiliki kemampuan adaptasi sosial yang baik dalam merespon perubahan sosial. Fenomena di lapangan yang mengungkapkan adaptasi sosial diwujudkan dengan nilai-nilai adat yang menjadi pedoman tata kelakuan masyarakat yang paling tinggi kedudukannya dan bersifat wajib untuk dijaga serta terintegrasi sangat kuat terhadap pola perilaku masyarakat yang memilikinya.

Kehidupan masyarakat Komunitas Adat Jalawastu saat ini memiliki ketahanan sosial dalam kemampuan transformasi yang sedang berkembang. Hasil penelitian menemukan adanya fenomena dilapangan menunjukan adanya pelaksanaan tranformasi/partisipasi di Komunitas Adat Jalawastu yang mulai dirasakan tahun 2012. Masyarakat di 
Komunitas Adat Jalawastu mulai mendapatkan perhatian melalui upaya regulasi untuk mempertahankan nilai adat dan budaya, oleh pemerintah desa, pemerintah daerah maupun pemerintah pusat. Selain itu, pembangunan fisik terkait dengan akses masuk ke Jalawstu sudah mulai diperbaiki selama lima tahun terakhir. Masyarakat Jalawastu mendapatkan pengembangan kapasitas dari Dinas Lingkungan Hidup dan Kehutanan (DLHK) Kabupaten Brebes untuk mengelola hutan adat yang terdapat di Komunitas Adat Jalawastu. Namun, kegiatan tersebut belum dapat diikuti oleh sebagian besar masyarakat Jalawastu mengingat terbatasnya sosialisasi dan pemahaman masyarakat dalam memberdayakan potensi yang tersedia.

Sebagian besar masyarakat Komunitas Adat Jalawastu belum dapat melakukan kegiatan transformasi dalam merespon perubahan sosial. Masyarakat Komunitas Adat Jalawastu merasa sulit untuk mengembangkan diri ke arah yang lebih baik dikarenakan berbenturan dengan nilai adat yang diwarisi secara turun termurun hingga saat ini. Sebagian masyarakat menginginkan untuk tidak terikat lagi dengan peraturan adat diperkembangan zaman yang kian modern, dengan cara pindah ke dusun lain atau merantau ke luar kota. Perilaku perpindahan masyarakat ini berdampak pada menurunnya partisipasi sumber daya manusia dalam mempertahankan nilai dan tradisi di Komunitas Adat Jalawastu.

Masyarakat Komunitas Adat Jalawastu juga belum merespon dengan baik terkait perkembangan transformasi pengelolaan sumber daya alam hutan adat yang diinisiasi oleh Dinas Lingkungan hidup dan Kehutanan. Masih banyak masyarakat Jalawastu yang belum berpartisipasi dalam kegiatan kelompok bersama mengelola hutan adat, yakni yang sedang dilakukan berternak madu (klanceng). Hal ini dikarenakan, kegiatan usaha bersama tersebut masih baru dilakukan di Bulan April 2021 yang lalu, sehingga masyarakat belum sepenuhnya mendapatkan pengetahuan dan pemahaman serta daya tarik dalam mengelola potensi alam yang tersedia, untuk meningkatkan kesejahteraan sosial.

Peningkatan kapasitas sumber daya manusia dalam mengolah potensi sumber yang tersedia, merupakan salah satu bentuk kegiatan tranformasi sosial di Komunitas Adat Jalawastu yang dapat dilakukan. Hal ini memiliki dampak positif untuk mengembangkan kearfian lokal yang bernilai ekonomis dan mampu menghasilkan pendapatan tambahan bagi masyarakat. Dengan kata lain, masyarakat Jalawastu dapat tetap terus melestarikan nilai dan tradisi adat seiring dengan perubahan sosial yang kian berkembang serta mampu memaksimalkan potensi alam maupun sosial untuk pembangunan potensi lokal dalam upaya meningkatkan kesejahteraan sosial.

Penelitian masih memiliki kekurangan mengenai aspek kemampuan transformasi dari ketahanan sosial di Komunitas Adat Jalawastu. Penelitian ini belum dapat menggali kemampuan transformasi secara penuh dan mendalam untuk menghadapi perubahan sosial di masa yang akan datang, mengingat ruang lingkup yang luas dari ketahanan sosial, sehingga perlu dilakukannya penelitian lebih spesifik terkait dengan kemampuan transformasi.

Peneliti menyarankan untuk penelitian selanjutnya untuk dapat menggali lebih mendalam terkait dengan upaya transformasi sosial yang lebih efektif untuk meningkatkan ketahanan sosial di Komunitas Adata Jalawastu dengan melibatkan pihak internal masyarakat Jalawastu dan beberapa pihak pemerintah daerah Kabupaten Brebes, dinas UMKM Kabupaten Brebes, dinas Perhutanan dan pihak yang lainnya, yang memiliki kewenangan 
untuk meningkatkan kemampuan transformasi di Komunitas Adat Jalawastu.

\section{DAFTAR PUSTAKA}

Adi Fahrudin. 2012. Pengantar Kesejahteraan

Sosial. Bandung: Refika Aditama.

Agus Suwignyo. 2018. Praktik

Kewarganegaraan Sehari-hari sebagai

Ketahanan Sosial Masyarakat Tahun

1950'an. Jurnal Ketahanan Nasional. Vol

24, 94-116. Diterbitkan April 2018.

Universitas Gajah Mada.

Daud Bahransyaf dan Ratih Probosiwi. 2013.

Membangun Ketahanan Sosial di Desa

Serakapi: Sebuah Replikasi Model. Jurnal

PKS Vol 12 No 3 September 2013; 225 236. Jakarta: Kementerian Sosial.

Dwi Heru Sukoco. 1991. Profesi Pekerjaan

Sosial dan Proses Pertolongannya.

Bandung: KOPMA STKS.

Enkeu Agiati. 2010. Peran Tokoh Adat dalam

Melestarikan Nilai Tradisi Komunitas Adat.

Jurnal Ilmiah Pekerjaan Sosial. Vol. 9, 85-

108. Diterbitkan Juni 2010. STKS Bandung.

Isbandi Rukmito Adi. 2012. Intervensi

Komunitas: Pengembangan Masyarakat sebagai Upaya Pemberdayaan Masyarakat. Jakarta: Raja Grafindo Persada.

Jacobus Ranjabar. 2017. Perubahan Sosial

Teori-teori, dan Proses Perubahan Sosial serta Teori Pembangunan.Cetakan Kedua. Bandung: Alfabeta.

Keraf, A. S. 2010. Etika Lingkungan Hidup. Jakarta: Kompas.

Markus Keck and Patrick Sakdapolrak. 2013. What is Social Resilience? Lessons Learned and Ways Forward. Bonn: Erdkunde. Vol. 67 , no. 1, hh. 5-19.

Moleong, Lexy J. 2016. Metodologi Penelitian Kualitatif. Cetakan ke Ketiga Puluh Lima. Bandung: PT Remaja Rosda Karya.
Muhammad Fakhry Ghafur. 2016. Ketahanan sosial di perbatasan: Studi kasus pulau sebatik. Jurnal Masyarakat Indonesia Volume 42 No.2. Diterbitkan 2 Desember 2016. Lembaga Ilmu Pengetahuan Indonesia.

Nurul Hidayah, dkk. 2017. Ketahanan Sosial Pada Pemuda Penyelenggara Festival Film Dokumenter 2015. Jurnal Ketahanan Nasional Volume 23 halaman 158-174. Diterbitkan Agustus 2017. Universitas Gajah Mada.

Prisca Kiki Wulandari, dkk. 2020. Ketahanan Sosial Pemuda Dalam Pengelolaan Wisata Budaya. Jurnal Ketahanan Nasional Volume 26, Nomor 2. Diterbitkan Agustus 2020. Universitas Brawijaya.

Soerjono Soekanto dan Budi Sulistyowati. 2013. Sosiologi Suatu Pengantar. Cetakan ke-45. Jakarta: PT Raja Grafindo Persada.

Sugiono. 2016. Metode Penelitian Kuantitatif Kualitatif dan R\&D. Cetakan ke-23. Bandung: Alfabeta.

Theresia Martina M. dkk. 2017. Ketahanan Sosial dalam Menghadapi Perubahan Sosial Komunitas Adat Kampung Pulo di Kabupaten Garut. Jurnal Ilmiah Pekerjaan Sosial. Vol. 16, 281-301. Diterbitkan Desember 2017. STKS Bandung.

Zastrow, Charles. 2010. Social Work and Social Welfare. Canada: Brooks/Cole, Cengage Learning.

\section{Sumber Lain:}

Alianasi Masyarakat Adat Nusantara. Diakses di www.aman.or.id pada Rabu, 1 Agustus 2021.

Peraturan Presiden Republik Indonesia Nomor 186 Tahun 2014 tentang Pemberdayaan Sosial Terhadap Komunitas Adat Terpencil. Peraturan Menteri Sosial No. 08 Tahun 2012 
tentang Pedoman Pendataan dan

Pengelolaan Data Penyandang Masalah

Kesejahteraan Sosial dan Potensi dan

Sumber Kesejahteraan Sosial.

Undang-Undang Republik Indonesia Nomor 6

Tahun 2014 tentang Desa.

Undang-Undang Republik Indonesia Nomor 14

Tahun 2019 tentang Pekerja Sosial. 